\title{
Imaging the gods: animal mummies from Tomb 3508, North Saqqara, Egypt
}

Stephanie Atherton-Woolham ${ }^{1}$, Lidija McKnight ${ }^{1, *}$, Campbell Price ${ }^{2}$ \& Judith Adams ${ }^{3,4}$

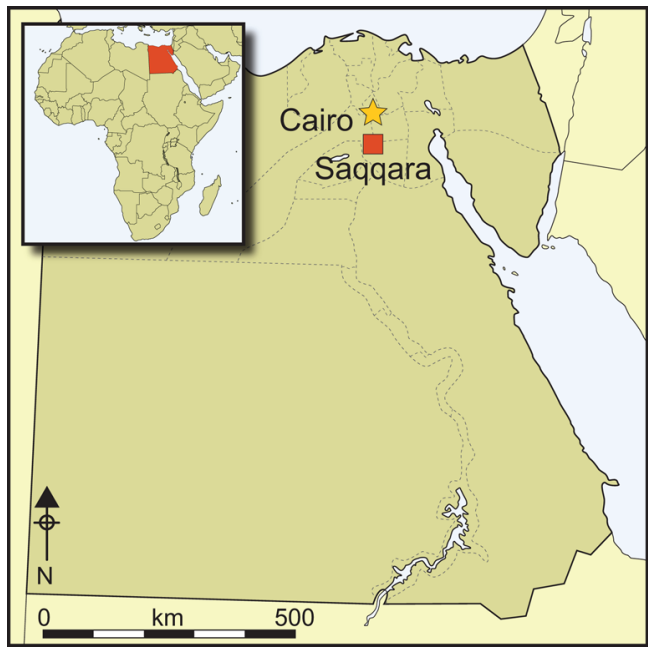

A collection of mummified animals discovered in 1964 in a Third Dynasty mastaba tomb at North Saqqara, Egypt, offers the unusual and unique opportunity to study a group of mummies from a discrete ancient Egyptian context. Macroscopic and radiographic analyses of 16 mummy bundles allow parallels to be drawn between the nature of their internal contents and their external decoration. The evidence suggests that incomplete and skeletonised animal remains fulfilled the equivalent votive function as complete, mummified remains, and that a centralised industry may have produced votive mummies for deposition at the Saqqara Necropolis.

Keywords: Egypt, Saqqara, animal mummies, votive offerings, experimental archaeology

\section{Introduction}

Animal mummies are commonly divided into four categories: pets, victual (preserved food), cult animals and votive offerings (Ikram 2015: 1-16), with the latter being the most common type found in museum collections around the world. Since 2010, research at the University of Manchester has collated data on these widely distributed objects (McKnight et al. 2011) to understand further their votive purpose. Minimally invasive clinical imaging is used to identify the materials and methods used in their construction to gain additional understanding of their votive purpose. To date, the project has analysed over 960 animal mummies, although

1 The University of Manchester, 3.503 Stopford Building, Oxford Road, Manchester M13 9PT, UK

2 Manchester Museum, Oxford Road, Manchester M13 9PL, UK

3 Radiology, Central Manchester University Hospitals NHS Foundation Trust and Manchester Academic Health Science Centre, Citylabs 1.0, Nelson Street, Manchester M13 9NQ, UK

4 Division of Informatics, Imaging \& Data Sciences, Faculty of Biology, Medicine and Health, University of Manchester, Oxford Road, Manchester M13 9PT, UK

* Author for correspondence (Email: lidija.mcknight@manchester.ac.uk)

(C) Antiquity Publications Ltd, 2019. This is an Open Access article, distributed under the terms of the Creative Commons Attribution licence (http://creativecommons.org/licenses/by/4.0/), which permits unrestricted reuse, distribution, and reproduction in any medium, provided the original work is properly cited.

ANTIQUITY 93367 (2019): 128-143

https://doi.org/10.15184/aqy.2018.189 
80 per cent of these have no known archaeological findspot or definitive association with a specific site. Of notable exception are those objects distributed to UK collections from the Egypt Exploration Society (EES) excavations at the Sacred Animal Necropolis, North Saqqara.

In 1964, while excavating a Third Dynasty mastaba tomb (a mud-brick, above-ground tomb structure) (3508) at North Saqqara, Walter Bryan Emery (1902-1971) encountered evidence of much later activity in the form of pilgrim graffiti in the brickwork, deposits of pottery and bull (Bos taurus) and ibis (Threskiornis aethiopicus) mummies. This tomb reuse interested Emery who, upon further investigation, discovered that the south burial shaft (Figure 1) and the main burial shaft of the adjacent tomb (3509) were filled with animal mummy bundles placed inside lidded pots. The pottery deposits, which included ibis jars and inscribed ostraca, indicated dates within the Ptolemaic Period (332-30 BC) (Emery 1965: 3; Ray 2013). Emery's clearance of the burial shaft in tomb 3510 to a depth of $10 \mathrm{~m}$ located the main axial corridor of the South Ibis Galleries. Branching off this corridor were numerous side-galleries containing votive animal mummies in ceramic vessels. Emery did not record the variety of animal mummies he discovered, describing them all simply as ibis mummies, presumably due to their conical shape (Emery 1965: 4 \& pl. IV). Despite the enormous potential of this discovery, Emery was disinterested in the finds, other than the possibility that they might lead to the identification of the "long-lost Asklepieion and [...] the tomb of Imhotep" (Emery 1965: 3), with whom he associated the animal cults at Saqqara (Nicholson et al. 2015: 647).

Emery's team examined more than 500 mummies, all contained within lidded pots (McKnight \& Atherton-Woolham 2015: cover). Due to an absence of dating evidence from the South Ibis Galleries, the mummies were attributed to the Late Ptolemaic Period (664-30 BC) (Martin 1981: 14). Emery noted fine herringbone patterns on the mummies, with appliqué designs depicting various gods, the uniformity of which he attributed to a single embalming workshop (Emery 1965: 4). Their pleasing aesthetic appearance probably influenced their selection for subsequent distribution to a number of museums in the UK.

Only 164 of the 500 mummies were recorded by Martin (1981), a disparity perhaps due to the excavation method, which involved many workers clearing the South Shaft, but far fewer recording the finds. This loss of information is perhaps understandable, considering the combination of cursory recording of Old Kingdom mastabas and later votive deposits, with Emery's habit of moving hastily between areas (Davies \& Smith 2005: 5). Aside from Emery's limited recording, it is unknown whether he and his team conducted any further study of the mummies and containers. The preliminary reports make no mention of such work, and Martin (1981: 15-16) records only the findspot references and current locations of the ibis mummies in museum collections, where known. Despite findspot references being available for the majority of the study group, it is uncertain whether the objects close or adjacent to one another in the finds list were deposited together, or were discovered and recorded at a later date. A decorative typology was formulated for some mummies (based on research undertaken by Anne Millard), which referenced differences in shape and style (Paul Nicholson pers. comm.). The present article re-contextualises the animal mummies recovered by Emery from the South Shaft of Tomb 3508 and currently curated in UK museum collections, enabling an interdisciplinary investigation of animal mummies from a discrete archaeological context. 


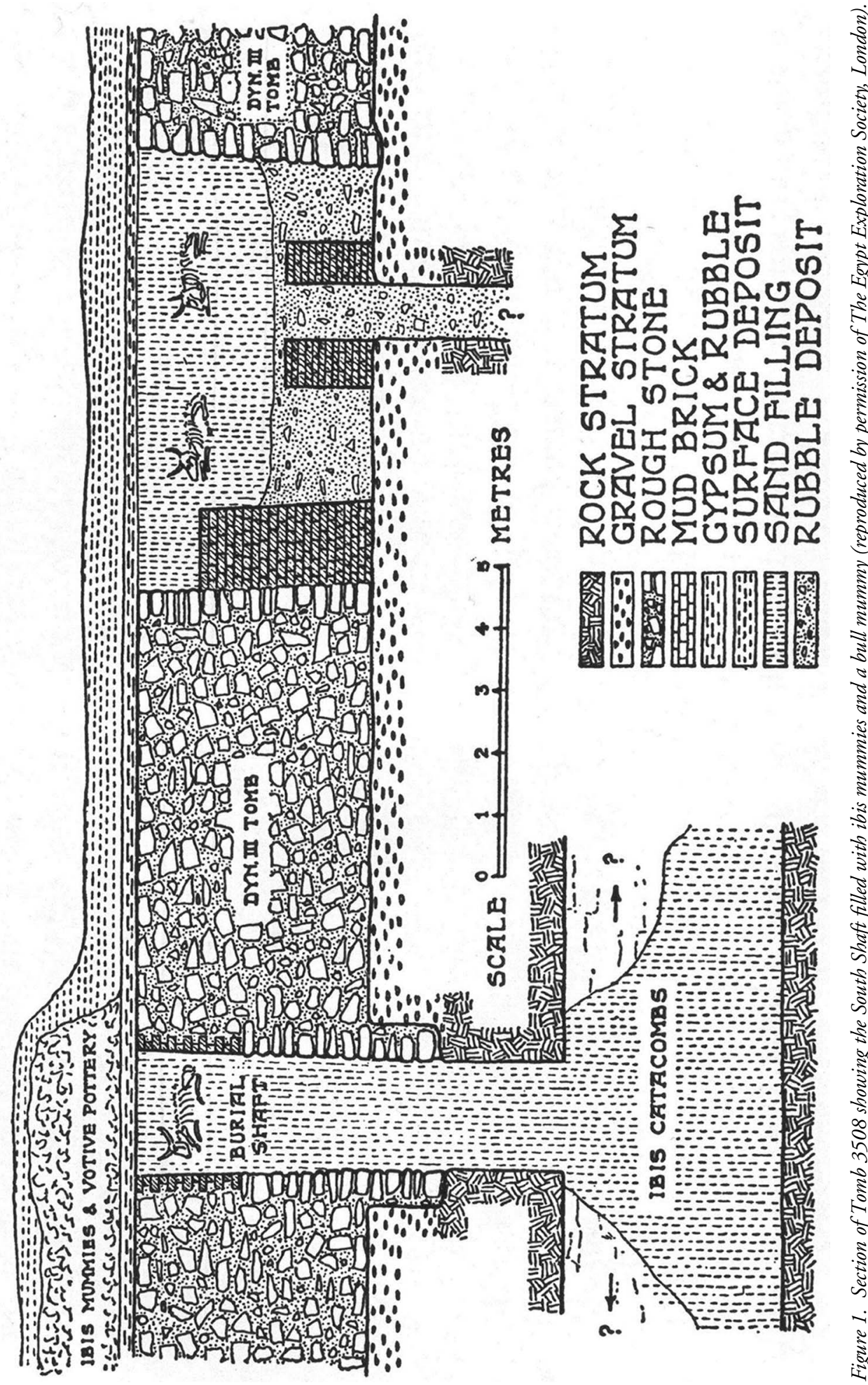

(C) Antiquity Publications Ltd, 2019 


\section{Object distribution to UK museums}

The reconstruction of the connections between Egyptian field excavation and museum collections has been a focus of recent study (Stevenson 2015; Stevenson et al. 2016). Martin (1981) records with illustrations and descriptions the archaeological finds recovered during the EES excavations of the southern areas of the Main Temple Complex, including a comprehensive concordance of museum and catalogue numbers relating to the post-excavation distribution of objects. Research at the University of Manchester has located 13 animal mummies originating from the South Ibis Galleries and South Shaft of Tomb 3508 in UK museum collections, along with three animal mummies that lack a findspot reference, but which have acquisition details indicating an association with the South Shaft (Table 1) (McKnight et al. 2011; McKnight \& Atherton-Woolham 2015: 64-94). A further six mummies are housed in the Egyptian Museum, Cairo (Martin 1981; Ikram \& Iskander 2002); the locations of those remaining are unknown. A number of animal mummies not recorded by Martin (1981: 15-16) have been identified in UK collections during the course of the current research, suggesting that, at the time of publication, Martin was unaware of the location of every mummy.

Museum archives and oral histories are important when reconstructing context. Museum correspondence indicates that financial support for excavations could be used to acquire finds; National Museums Liverpool, for example, used residual funds from their support of Nubian excavations during the 1905-1906 season to acquire material from Saqqara (Ashley Cooke pers. comm.). Although museums could not select specific items, they could indicate some preference in order to complement their existing collections (John Prag pers. comm.). Selected objects from the Saqqara excavations were displayed in a showcase exhibition at the British Museum in 1968, alongside artefacts discovered by the EES between 1952 and 1968 . While no object list for this exhibition survives, it appears that some of the animal mummies with appliqué designs may have been displayed (Egypt Exploration Society 1968: 13). The distribution of these objects to various UK museums was overseen by the British Museum, coordinated by T.G.H. James, then Keeper of Egyptian Antiquities.

\section{Modern research protocol}

Non-invasive macroscopic and radiographic techniques developed by the authors at the University of Manchester were conducted between 2011 and 2016 on 16 mummies from nine museums (Table 1) (McKnight \& Atherton-Woolham 2015: 64-94; McKnight et al. 2015). Digital photography of the external appearance was conducted, with measurements and observations noted on a recording proforma. Drawings were used to capture complex decorative details that were difficult to document with photographs. Clinical imaging detailed the internal construction and nature of the bundle contents. Digital radiography (DR) was conducted using a Philips Eleve Digital Diagnostic system (Eindhoven, the Netherlands) at a standard exposure of $57 \mathrm{kV}, 1 \mathrm{mAs}$ with a focal spot size of $0.6 \mathrm{~mm}$. Computed tomography (CT) was conducted using a Siemens Somatom Definition AS+ (Siemens Healthcare, Malvern, PA) 128-detector row multi-detector spiral CT (120 kVp, $200 \mathrm{mAs}$, pitch of 0.969:1, 0.6 -second rotation, $0.625 \mathrm{~mm}$ section thickness). 
Stephanie Atherton-Woolham et al.

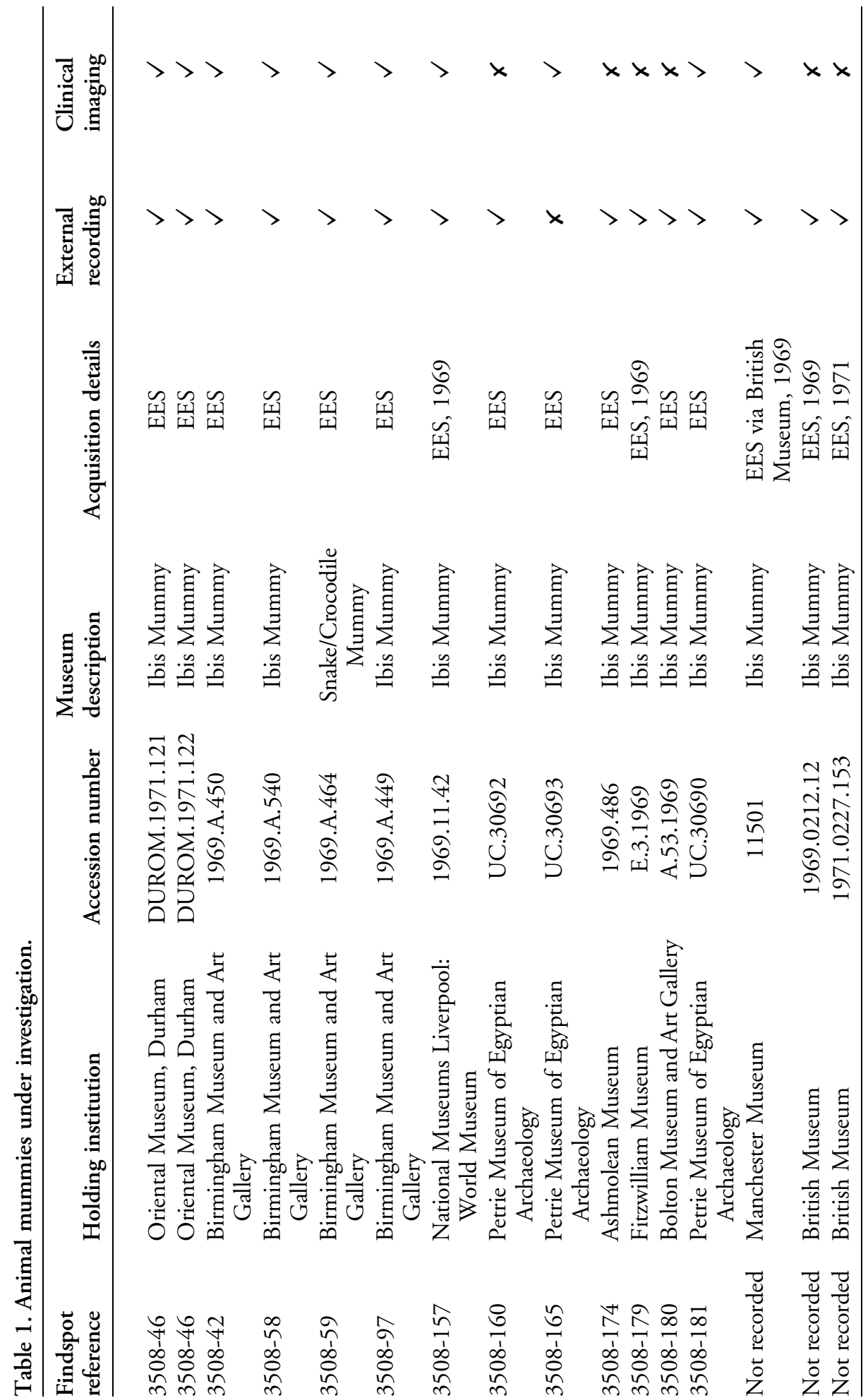

(C) Antiquity Publications Ltd, 2019 


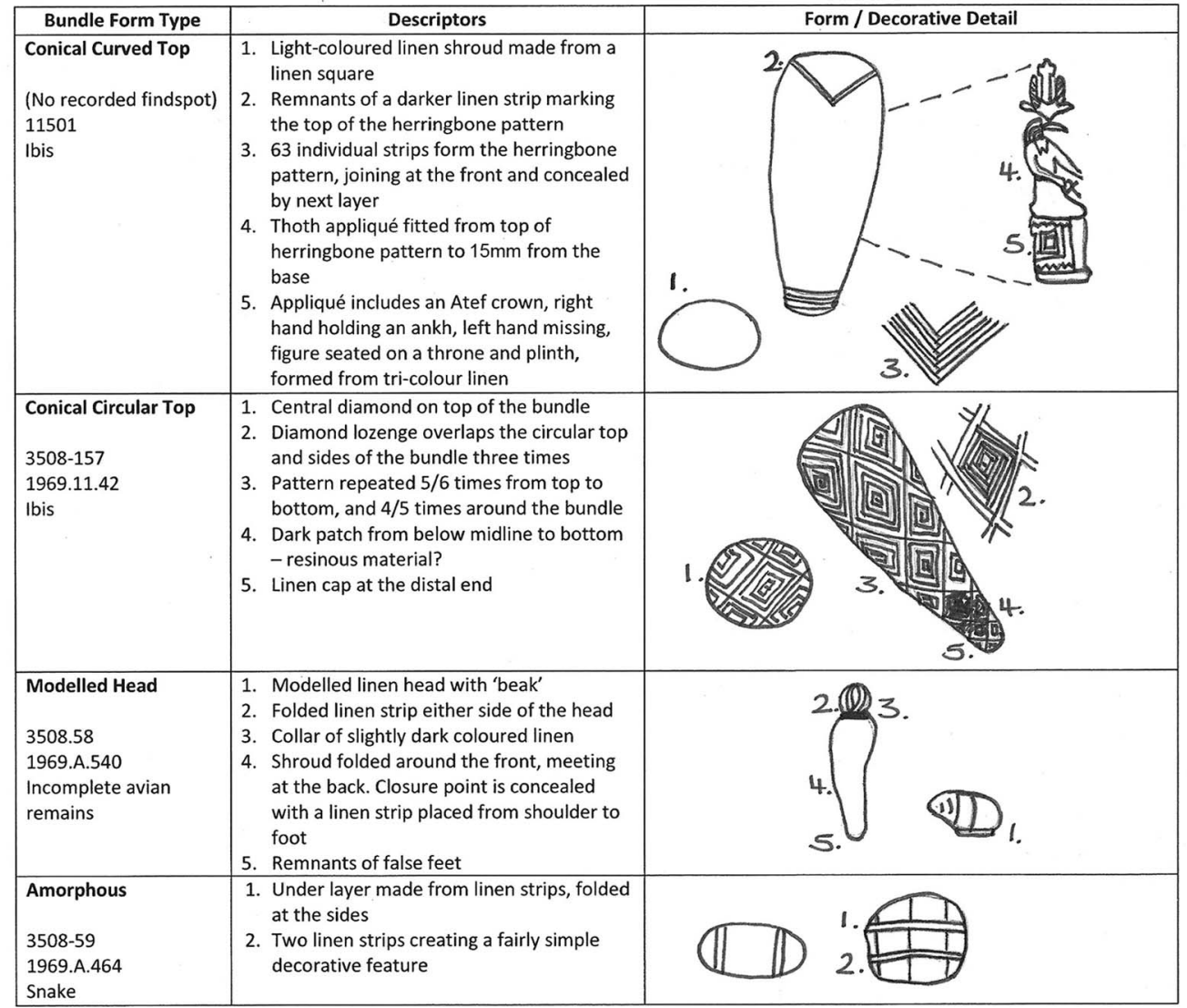

Figure 2. Form types and decorative details in the study group (illustration by Lidija McKnight).

\section{Results}

\section{Form and contents}

The 16 mummies in the study group are classified as follows: conical curved-top, conical circulartop, modelled head with plain body shroud and amorphous (Figure 2 \& Table 2). Radiography demonstrates that the bundles are form-specific, and only two conical bundles (3508-181 and 11501) contained single, complete, articulated individuals at the time of mummification.

Bundle 3508-59 is amorphous and was described by Martin (1981: 16) as a mummified snake, presumably because its size and shape is consistent with other mummy bundles containing small mammals and reptiles (McKnight \& Atherton-Woolham 2015: 77). Radiography demonstrates the contents to be three crania plus articulated limbs-presumably belonging to the same individuals — of a species of shrew (Sorcidae sp.) (Figure 3).

Bundle 3508-58 comprises a modelled head and plain body shroud. Although described in museum records as an ibis, it is more consistent in size and form with that of a small bird of prey (McKnight \& Atherton-Woolham 2015: 77). Modelled heads in ibis mummies appear 
Stephanie Atherton-Woolham et al.

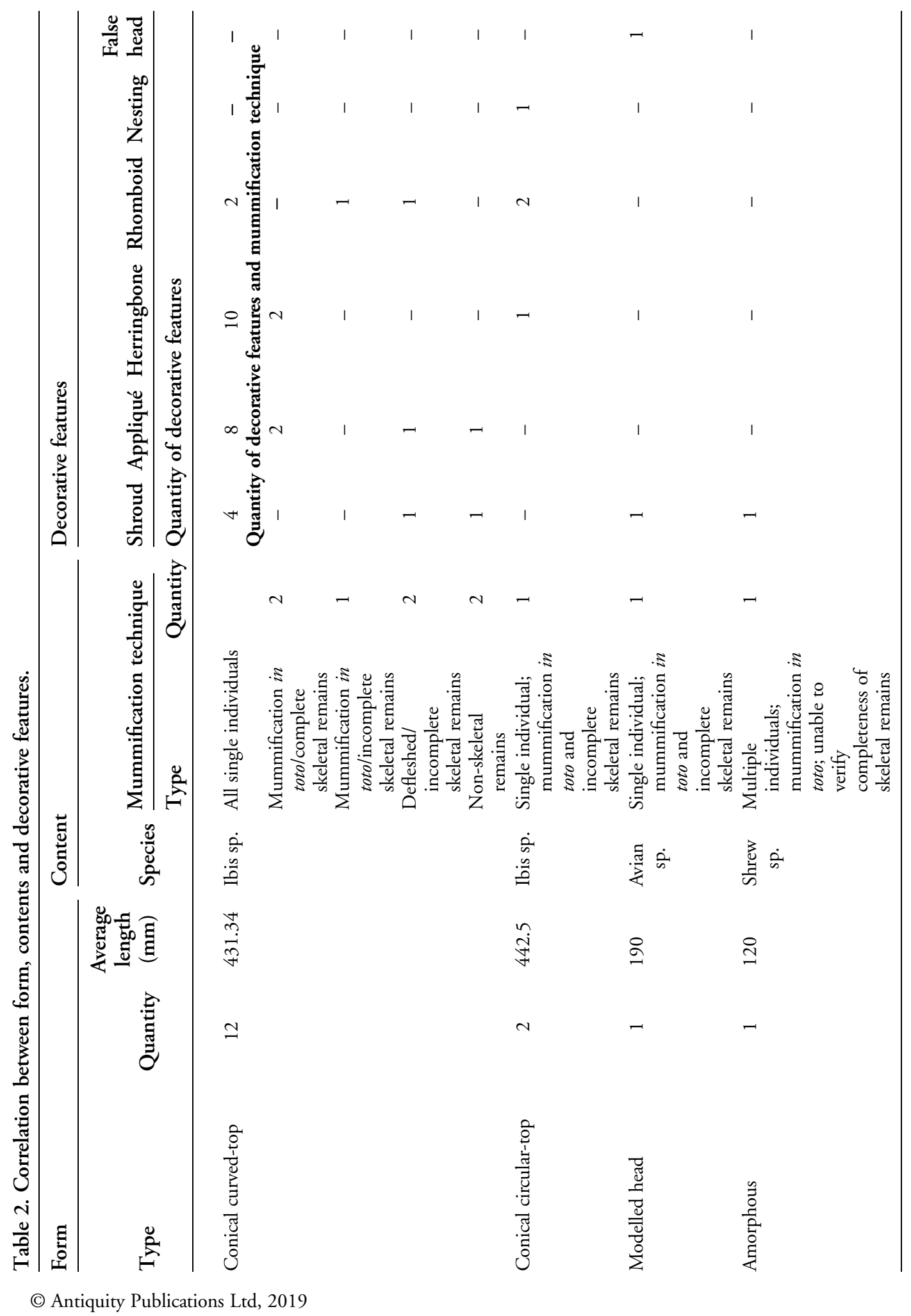




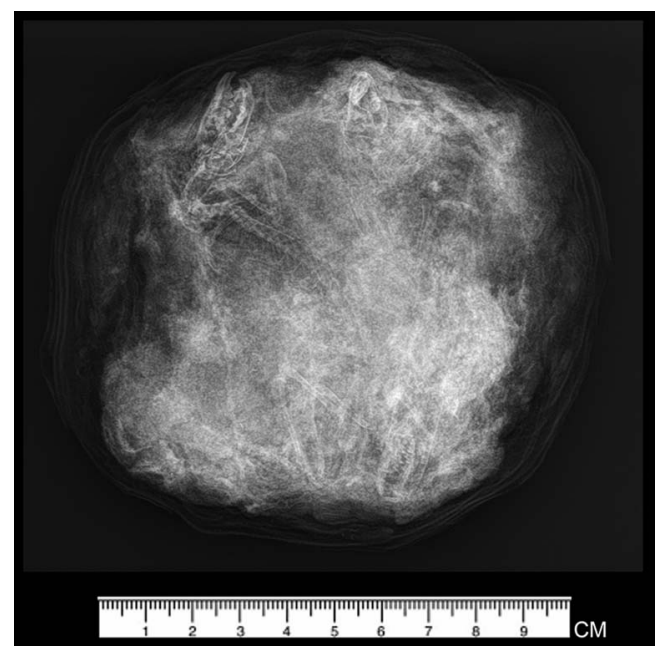

Figure 3. AP digital radiograph showing the contents of 3508-59 with an MNI of 3, demonstrated by three skulls of shrew species (reproduced by permission of the Birmingham Museum and Art Gallery and the Central Manchester University Foundation Trust). infrequently - and rarely from a Saqqara context. Where they do occur, they are false accoutrements constructed from linen and resinous substances, attached to conical bundles, within which are the skeletal remains. Clinical imaging reveals a radiodense core containing a single avian wing (humerus, radius, ulna and carpometacarpus) in the broadest part of the bundle, with no other discernible skeletal content (Figure $\mathrm{S} 1$ in the online supplementary material (OSM)). Feathers, evidenced in axial CT images by air voids in the calamus and rachis, appear to be attached to the wing; these add length to the bundle core and demonstrate that the remains were not skeletonised, but rather mummified in toto (Kessler \& Nur el-Din 2015: 142).

The remaining mummies were conicalshaped bundles. Imaging demonstrated the presence of non-skeletal and skeletal remains: two bundles contained a core of feathers and eggshell, supported by linen rolls (Figure S2). Eight bundles contained avian skeletal material, all of which appeared consistent in size and morphology with ibis species. Two bundles contained incomplete skeletal remains of a single ibis individual, which appear to be completely skeletonised, indicating that soft tissue or feathers were not present at the time of wrapping (Figure S3). Four bundles contained unidentifiable avian skeletal remains that were mummified in toto, of which two were the incomplete skeletal remains of a single individual (Figure S4), and two were probably complete ibises at the time of mummification. The latter had suffered significant postdepositional damage to the thoracic spine (Figure 4). This suggests a lack of evisceration during mummification, which resulted in biological degradation of the internal organs, which in turn resulted in the collapse of delicate structural elements, such as the ribcage (Ikram 2015: 22).

\section{Construction}

Clinical imaging and analysis of damaged areas allows for the delineation of stages in the construction of the mummy bundles (Table 3). This includes a distinct similarity in the radiodense appearance of the bundle cores due to the application of a resinous substance during their preparation. Experimental work has shown this is to be a vital step, both for preservation and for practical reasons by acting as an adhesive to fix the linen layers (Atherton \& McKnight 2014). It is evident that stage 1 is comparable to animal mummies excavated by the EES in the Falcon Catacombs, where animal remains were simply "sewn into a coarse linen bag" (Davies \& Smith 2005: 8) before being shaped into bird-like forms using linen pads and rolls (Figure S4). The major variation in this stage between the Falcon Catacombs and the

(C) Antiquity Publications Ltd, 2019 

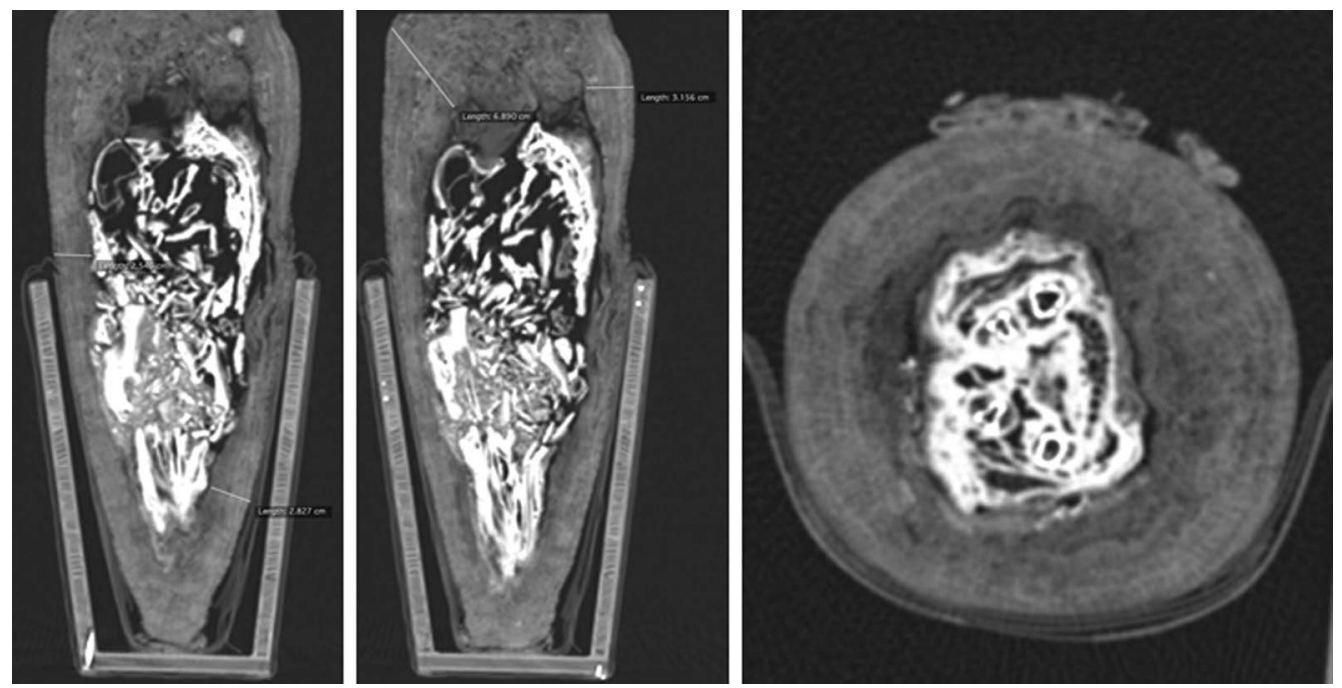

Figure 4. Axial and reformatted coronal CT slices showing the contents of 11501 as an example of mummification in toto of a complete ibis (reproduced by permission of the Manchester Museum and the Central Manchester University Foundation Trust).

South Shaft mummies, however, was the amount of linen used, which varied greatly in thickness between 5 and $50 \mathrm{~mm}$ at the densest point (Figure 4).

\section{Decorative features}

There are six types of external decoration: shroud, herringbone, lozenge, nesting, circular strips and appliqué (Figure 5). One bundle (3508-165) is omitted here, as it is missing most of the outer decorative features. Bundles 3508-58 and 3508-59 are simply decorated, compared to the multiple decorative features exhibited in the conical bundles. Herringbone and appliqué-only used in curved-top conical bundles - are the most frequent designs, whereas more complex rhomboid designs (either nesting or herringbone) are used for circular-top conical bundles. Appliqué motifs, inspired by divine iconography, are constructed from various shades of natural linen (Hallmann 2015: 122), with a resinous substance or linen string — both dark in colouration-used to highlight details in clothing and anatomy.

\section{Discussion}

\section{Production patterns in the South Ibis Galleries, North Saqqara}

The conical bundles were uniformly produced in a shape synonymous with the ibis that they contained. Whether this uniformity was determined by the contents alone, or by the shape of the 'ibis-pot' in which the mummy bundles were placed (McKnight \& Atherton-Woolham 2015: cover image), remains uncertain; analysis of the contents of curved-top and circulartop conical bundles suggests that the ceramic pots may be the motivating factor. Bundle shapes could also be the result of the proportion of the animal(s) contained within. In particular, the circular-top bundles have a greater proportion of linen-to-animal remains, which dictates the bundle form. This suggests that the animal mummies from the South Ibis (C) Antiquity Publications Ltd, 2019 
Table 3. Common and anomalous stages in mummification of animal mummy bundles in the study group.

\begin{tabular}{|c|c|c|}
\hline Stage & Common features & Construction anomalies \\
\hline 1 & $\begin{array}{l}\text { Core comprising animal material, sometimes } \\
\text { placed in anatomical order, and wrapped } \\
\text { in an initial linen layer, followed by a } \\
\text { resinous coating. }\end{array}$ & $\begin{array}{l}3508-59 \text { featured a central linen pad, on } \\
\text { top of which the animal remains were } \\
\text { placed before being wrapped in a linen } \\
\text { layer and coated with resin. }\end{array}$ \\
\hline 2 & $\begin{array}{l}\text { Circumventing knotted linen/plant fibre } \\
\text { strips to make a single piece, } \\
\text { approximately } 15 \mathrm{~mm} \text { wide. }\end{array}$ & Not visible in $3508-59$. \\
\hline 3 & $\begin{array}{l}\text { Multiple linen pieces covered the bundle, } \\
\text { probably sourced from different 'leftover' } \\
\text { pieces evidenced by lengths and weaves, } \\
\text { and were attached to areas where the fit was } \\
\text { optimum. }\end{array}$ & - \\
\hline 4 & $\begin{array}{l}\text { Linen string covered the bundle in } \\
\text { horizontal circles to hold the multiple } \\
\text { linen pieces in place. }\end{array}$ & - \\
\hline 5 & $\begin{array}{l}\text { Linen shroud that covered the linen layer and } \\
\text { acted as a base for the decorative features. }\end{array}$ & $\begin{array}{l}\text { A single shroud did not cover the entire } \\
\text { bundle in every instance. In } 3508-58 \text {, a } \\
\text { single rectangular strip, applied to the } \\
\text { underside, covered the gap left by the } \\
\text { shroud. In } 3508-46 \text { and } 3508-165 \text {, the } \\
\text { shroud left a gap on the upper aspect of } \\
\text { the bundle. This was partially concealed } \\
\text { in } 3508-46 \text { with a heavy string layer in a } \\
\text { rhomboid and circular design. Damage } \\
\text { to 3508-165 does not permit analysis of } \\
\text { the final layer in this bundle, but the } \\
\text { remains of an associated appliqué piece } \\
\text { suggest it may once have been concealed. }\end{array}$ \\
\hline 6 & Decorative features & - \\
\hline
\end{tabular}

Galleries were required to conform to a conical shape in order to fit within the ceramic containers. The exceptions are the two non-conical bundles 3508-58 and 3508-59. Contextual information is lacking as to whether these were originally included in individual pots, as an assemblage within a single pot or from a different context altogether. Their distinct form separates them from the ibis bundles, yet they were intentionally deposited within galleries intended for ibises. This 'confusion phenomenon', where burials of different species are interred together, is common at Saqqara and at other animal necropoleis (Ikram 2007: 418; Nicholson et al. 2015: 655). It is interesting that, within a catacomb containing conical mummy bundles with ibis contents (or birds that resemble ibises), there was a deliberate attempt to create a distinctive external appearance.

The mummies in the studied group show striking similarities in mummification method, bundle construction and wrapping technique. Each mummy demonstrates at least five out of 


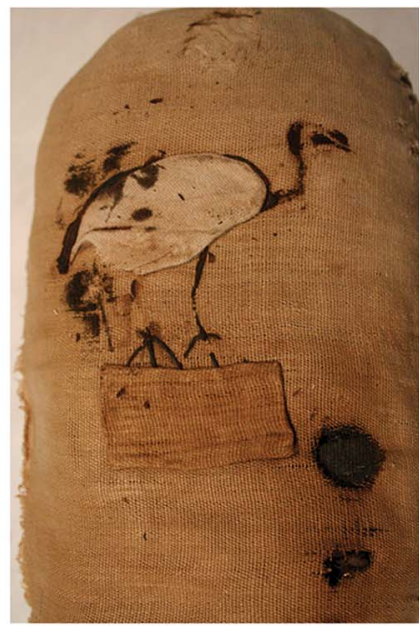

3508-166, Durham

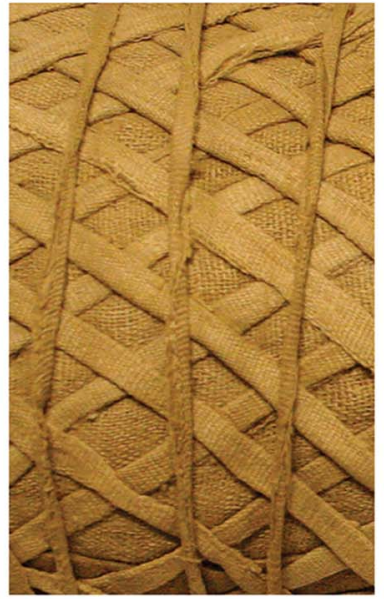

3508-42, Birmingham

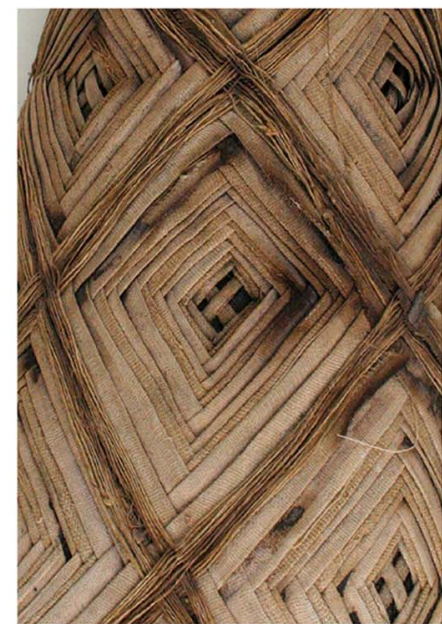

3508-157, Liverpool

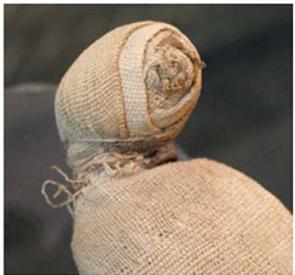

3508-58, Birmingham

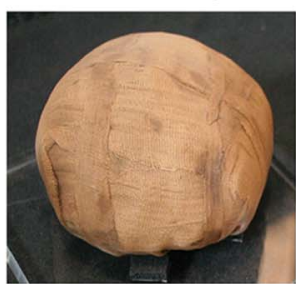

3508-59, Birmingham

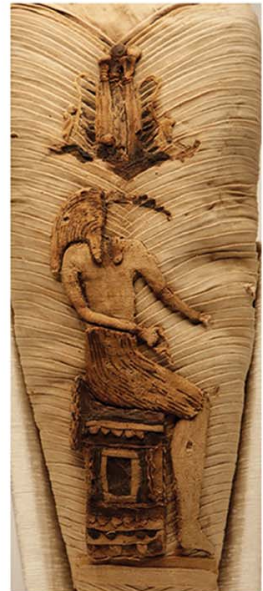

$11501, \mathrm{M}$ anchester

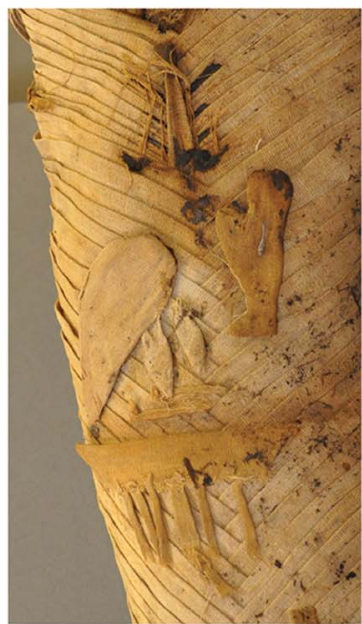

3508-160, Petrie

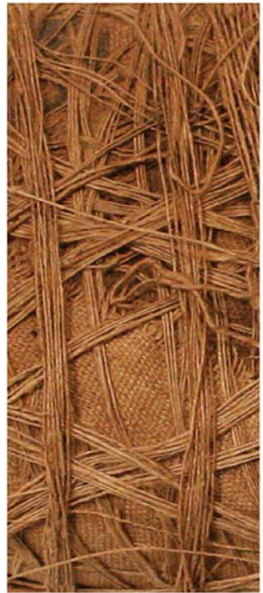

3508-46, Durham

Figure 5. Montage image of decorative features in the study group (clockwise from top left): 3508-166 (Durham): appliqué ibis standing on a plinth; 3508-157 (Liverpool): elaborate nested lozenge design formed from linen strips and thread; 3508-160 (Petrie): herringbone with applique design; 3508-42 (Birmingham): simple lozenge design with circular strips; 3508-58 (Birmingham): shroud with simple modelled head; 3508-59 (Birmingham): amorphous shape with simple design of overlapping circular strips; 11501 (Manchester) fine herringbone with shroud cap and applique design; 3508-46 (Durham): shroud covered with concentric and lozenge thread layers (photographs by Lidija McKnight).

the six possible stages (Table 3). A circumventing linen or plant fibre strip (stage 2 ) is evident in the conical bundles (Figure S4). The present authors have previously noted the use of plant fibre in bovid mummies, probably to secure the form of larger bundles (McKnight \& Atherton-Woolham 2015: 78-81). In addition, the reuse of 'linen scraps', linen pads and false accoutrements is recorded in animal and human mummies as a means of creating shape, rather than for securing the contents (Ikram \& Dodson 1998: 162; Raven \& Taconis 2005: 201).

(C) Antiquity Publications Ltd, 2019 
Conical mummy bundles exhibiting two decorative features were conservative in design. Herringbone and shroud designs provide a suitable layer upon which to apply an appliquéd divine image, whereas rhomboid, nesting and string designs add a layer of complexity that could, if combined with an appliqué, be perceived as hyperbolic. The round-top conical bundles lack appliqué-presumably because the bundle form would have complicated visualisation of the divine image. In contrast, the flat profile of curved-top bundles was conducive to the placement of an appliqué and the increased visibility of the divine image.

While the appliqués are characteristic of divine iconography, each example shows subtle differences in the individual elements that make up the image. Thrones combine bi-coloured linen squares in a chequerboard pattern, linen string applied horizontally and vertically and an elaborate bi-coloured window and frilled pattern-all of different heights and widths. Body parts of the deities display anomalies, such as in the case of the legs of Thoth on bundles 3508-179 and 11501, where the distance from the throne and width of the calf are different. In addition, the varying dimensions of the curved-top conical mummy bundles influenced the design on the front, with some filling the space while others appear more centralised. This evidence suggests that an individual was responsible for constructing an appliqué in its entirety, rather than being responsible for creating individual pieces for several different appliqués, which would have resulted in uniformity across the design range.

\section{Experimental approach to the creation of appliqués}

As noted by recent studies, a thorough understanding of the techniques and challenges involved in object construction can be gained from experimentation (Atherton \& McKnight 2014; Szpakowska \& Johnston 2016). In the present study, macroscopic and radiographic imaging has proved useful in the non-invasive visualisation of the construction stages of animal mummies. Defining the production of appliqués was, however, more difficult. Macroscopic inspection permits external details in the appliqués to be highlighted, but the restricted spatial resolution when radiographing flat objects (McKnight et al. 2015: 2119) means that internal details are undefined.

In 2016, the wrappings and decorative features of bundle 11501 were reconstructed for a public engagement event in Manchester (McKnight 2018). This experimental reconstruction demonstrated how the ancient craftsperson created the $3 \mathrm{D}$ effect in the appliqué from the individual elements (i.e. body parts, throne and crown). Reconstruction of this feature was simple, although a very skilled hand was required. Reconstructing depth in the experimental Thoth appliqué, however, proved challenging. A damaged area on the original appliqué suggests that its flat appearance was probably created by multiple linen layers, formed to the current shape and covered with a piece of linen. We suspect that this was sealed on the underside, but have been unable to verify this using non-invasive techniques. The appliqué reconstruction, which created an appearance characteristic of the embroidery technique known as raised- or stump-work (Paul Nicholson pers. comm.), required a significant amount of time (two days) but not materials; overall, the experiment used fabric measuring $0.5 \times$ $1.52 \mathrm{~m}$ wide, together with manipulated offcuts to create smaller features. It was acknowledged that modern investigators were attempting to recreate this decorative style for the first time, whereas the ancient craftspeople had perfected artisanal techniques for votive

(C) Antiquity Publications Ltd, 2019 


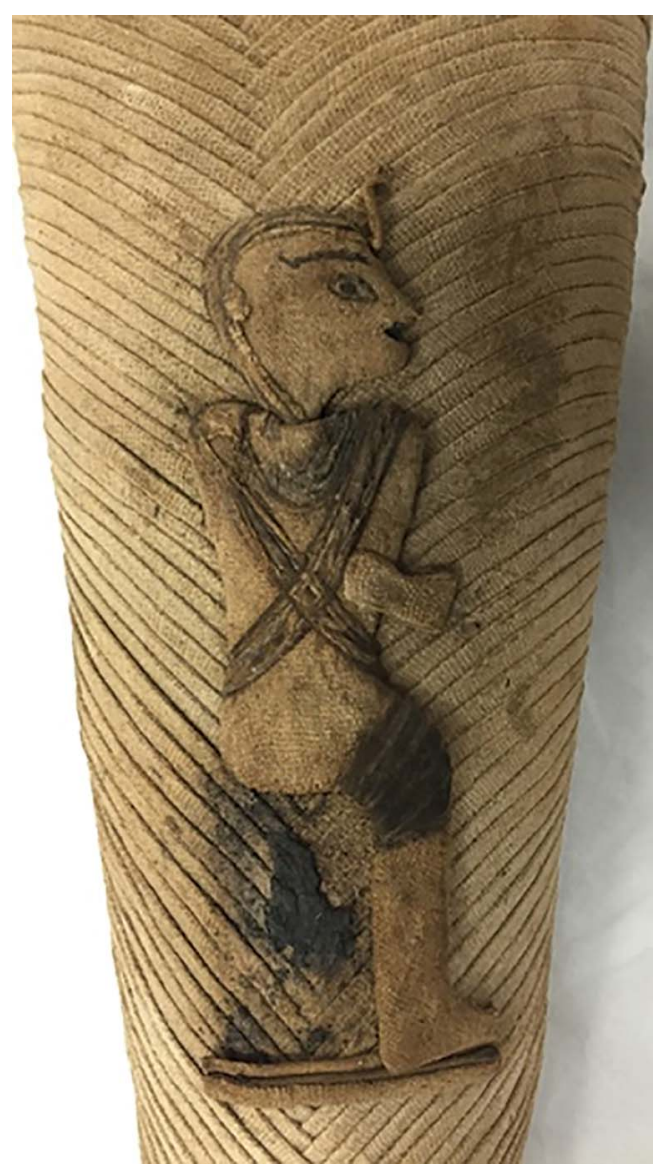

Figure 6. Appliqué linen image of Ptah (photograph by Lidija McKnight). production, which would clearly have simplified and expedited the process. The experiment concluded that, while the technique is very different, the level of skill and time required to create such a piece are comparable with those demonstrated by the other 3D votive objects discovered by Emery at Saqqara displaying divine iconography (such as bronze statuettes).

\section{Representation of deities on animal mummy bundles}

Identifying individual deities on votive mummy bundles is important in understanding the interaction of the animal cults with particular gods during the Late to Roman Periods (664 BC-AD 311). Both male and female deities are represented in this collection of mummies, delineated by three details: stance, arm position and clothing. Identification of the deities is further complicated due to damage. It seems reasonable, however, to suggest that the deities represented on the mummies are consistent with those presented in the form of votive bronzes from Saqqara (Martin 1981). The only female figure depicted on the mummies-representing either Hathor or Isis - is wearing a sheath dress, with her right arm by her side. In contrast, males - in this case Thoth and Nefertum - are shown wearing a kilt, with their right arm reaching across their body, over their lap.

One example is described by Emery as representing Imhotep (Emery 1965: 4), a seemingly reasonable identification, as Imhotep was connected to the Sacred Ibis in his epithet 'he of the ibis' (Lichtheim 2006: 96). When coupled with Emery's preoccupation with the location of Imhotep's tomb (Ray 2001: 20-22), however, this is perhaps a case of overenthusiastic identification of an anthropoid figure. Instead, the figure appears to be similar in appearance to either Osiris or Ptah, as evidenced by the mummiform body shape complete with mummy straps (Figure 6). The inclusion of the ureaus - the stylised depiction of a serpent indicating royalty or divinity — would further suggest that this is not Imhotep (Wildung 1977: 39-43), although if this is Osiris, his crown is missing; the individual, therefore, is probably Ptah. In the city of Memphis — of which Ptah was patron deity-he was associated with Thoth in the form of the baboons that lived "under his moringa-tree", within the sacred (C) Antiquity Publications Ltd, 2019 
confines of Ptah's temple (Thompson 2012: 5). The inclusion of an appliqué of Ptah on a Saqqara mummified ibis, an animal also sacred to Thoth, is a fitting connection.

Two examples in animal form are represented in this group, both of which appear to be ibises (Figure 5). The first (3508-166) is relatively plain, with linen appliqué and dyed linen string to represent the sacred ibis, shown standing upon a divine plinth. The second (3508-160) is more complex, comprising the partial remains of an ibis wearing an Atef crown, on an elaborate divine standard, facing the squatting figure of the goddess Maat. This combination is commonly seen in amulets and a stela showing sacred birds (ibis and hawk). Furthermore, the depiction of a feather of Maat is known from Petrie's $1915 \mathrm{Mem}$ phis excavations-possibly at the Great Ptah-temple area (Engelbach et al. 1915: pl. lx; Ray 2013: 237). Thus, it is a commonly encountered divine scene, although it is unique in this group and is the only one- to the authors' knowledge- to be found on a votive mummy.

\section{Conclusions}

Artefact-based studies requiring access to and investigation of material on archaeological sites located in Egypt are difficult due to the fragile political situation in the country and the legal embargo on the removal of material from the country, even for the purposes of scientific analysis. Researchers therefore seek suitable artefacts from museum collections outside of Egypt. As the majority of mummified animal material in museum collections lacks reliable provenance information, the ability to analyse a group of animal mummies from a discrete archaeological context-in this case, the South Shaft of Tomb 3508 at Saqqara-presents a unique research opportunity. The variety of wrapping styles identified within this context are of particular archaeological relevance, enabling a stylistic typology to be suggested. Rhomboid lozenge designs were previously assigned to the Roman Period (30 BC-AD 311) (Ikram \& Dodson 1998: 164), yet examples are found on a large scale in association with those stylistically attributed to the Late to Ptolemaic Periods (664-30 BC). This suggests discrepancies with the use of dating criteria based upon human mummification techniques. Radiocarbon dating of this material would help in the construction of a stylistic chronology for animal mummies, and would thus define the stylistic progression between human and animal mummies.

When combined with the different animal content found in this assemblage, the stylistic variety appears to be further evidence for the lack of importance placed by the ancient Egyptians on the incomplete nature of the animal remains found within mummy bundles. This suggests that mummies manufactured from incomplete skeletal material or from non-skeletal material, such as feathers, dung or organic matter, were considered to fulfil the same votive function as those containing complete remains.

These objects share the common Pharaonic iconography that appears on religious material, suggesting a similar end-purpose: a device through which one might address the gods. The issue of the relative value of these items is difficult to assess, as information on exactly how and why these items were made remains uncertain. It is possible that individual pieces were commissioned—as seen with other ritual items (Hill 2007: 153)—or perhaps that they were produced en masse before being magically 'activated' by way of ritual anointment and incantation following selection by an individual or their representative

(C) Antiquity Publications Ltd, 2019 
(Pinch \& Waraksa 2009: 6). Whereas votive bronzes found at Saqqara demonstrate considerable variation in their form, style and quality-perhaps suggesting multiple craftspeople and production sites (Davies \& Smith 2005) - the uniformity in decorative style and shape of the votive mummies is further evidence that these offerings are unlikely to have been produced by pious individuals. Instead, the evidence supports Emery's initial assertion that votive mummies were produced by a single embalming workshop operating within a centralised or semi-centralised industry at the Sacred Animal Necropolis, North Saqqara.

\section{Acknowledgements}

The authors would like to thank the museum curators and conservators who made available their animal mummies and archives for this research. Special thanks go to John Prag, of the Manchester Museum, who provided his account of the distribution process from the Saqqara excavations. The Radiology Directorate of the Central Manchester University Foundation Trust allowed out-of-hours access to imaging equipment, with radiography and CT scanning performed by Susan Crimmins and colleagues. We also wish to thank Robert Hill, HCA International, for assistance with imaging mummies at the Portland Hospital, London; and Judith White, of the Natural History Museum Bird Group at Tring, for zooarchaeological identification. In addition, thanks go to the Egypt Exploration Society for permission and access to archives. Lastly, the support of the Arts and Humanities Research Council (research grant AH/P005047/1), The Leverhulme Trust (research project grant RPG-2013-146) and Wellcome Trust (people awards 106317/Z/14/Z) are gratefully acknowledged.

\section{Supplementary material}

To view supplementary material for this article, please visit https://doi.org/10.15184/aqy. 2018.189

\section{References}

Atherton, S.D. \& L.M. McKnight. 2014. The mummification of votive birds: past and present (Proceedings of the $7^{\text {th }}$ UK Experimental Archaeology Conference, Cardiff 2013).

Available at:

http://journal.exarc.net/issue-2014-1 (accessed 28 November 2018).

Davies, S. \& H.S. Smith. 2005. The Sacred Animal Necropolis at North Saqqara. The Falcon Complex and catacomb: the archaeological report. London: Egypt Exploration Society.

Egypt Exploration Society. 1968. Exhibition of recent discoveries in Egypt and the Sudan by the Egypt Exploration Society at The British Museum, $16^{\text {th }}$ October-30 $0^{\text {th }}$ November 1968. London: Egypt Exploration Society.

EmerY, W.B. 1965. Preliminary report on the excavations at North Saqqara 1964-5. Journal of Egyptian Archaeology 51: 3-8.

Engelback, R., M.A. Murray, H.U. Petrie \& W.M.F. Petrie. 1915. Riqqeh and Memphis VI. London: British School of Archaeology in Egypt.
Hallmann, A. 2015. More items of funerary linen from the Deir el-Bahari burial assemblages. Polish Archaeology in the Mediterranean 24: 113-36. https://doi.org/10.5604/01.3001.0010.0178

Hill, M. (ed.). 2007. Lives of the statuary, in Gifts for the gods: images from Egyptian temples: 153-66. New Haven (CT): Yale University Press.

IKRAM, S. 2007. Animals in the ritual landscape at Abydos: a synopsis, in Z. Hawass \& J. Richards (ed.) The archaeology and art of ancient Egypt: essays in honor of David B. O'Connor: 417-32. Cairo: Supreme Council of Antiquities Press.

IKram, S. (ed.). 2015. Divine creatures: animal mummies in ancient Egypt. Cairo: The American University in Cairo Press.

Ikram, S. \& A. Dodson. 1998. The mummy in ancient Egypt: equipping the dead for eternity. London: Thames \& Hudson.

IKRAM, S. \& N. IsKander. 2002. Catalogue général of Egyptian antiquities in the Cairo Museum. Nos. 24048-24056; 29504-29903 (selected); 51084 51101; 61089 non-human Mummies. Cairo: The Supreme Council of Antiquities.

(C) Antiquity Publications Ltd, 2019 
Kessler, D. \& A.H. Nur el-Din. 2015. Tuna al-Gebel: millions of ibises and other animals, in S. Ikram (ed.) Divine creatures: animal mummies in ancient Egypt: 120-63. Cairo: The American University in Cairo Press.

Lichtheim, M. 2006. Ancient Egyptian literature III: the Late Period. Berkeley: University of California Press.

Martin, G.T. 1981. The Sacred Animal Necropolis at North Saqqara: the southern dependencies of the main temple complex. London: Egypt Exploration Society.

McKnight, L. 2018. 'Re-rolling' a mummy: an experimental spectacle at Manchester Museum. Experimental Archaeology 2018. Available at: https://exarc.net/issue-2018-1/ea/re-rollingmummy-experimental-spectacle-manchestermuseum (accessed 28 November 2018).

McKnight, L. \& S. Atherton-Woolham. 2015. Gifts for the gods: animal mummies and the British. Liverpool: Liverpool University Press.

McKnight, L., S. Atherton \& A.R. David. 2011. Introducing the ancient Egyptian Bio Bank at the KNH Centre for Biomedical Egyptology, University of Manchester. Antiquity Project Gallery 85(329): Available at http://www.antiquity.ac.uk/projgall/ mcknight329/ (accessed 28 November 2018).

McKnight, L., S. Atherton-Woolham \& J. AdAMs. 2015. Imaging of Egyptian animal mummies. RadioGraphics 35: 2108-20. https://doi.org/10.1148/rg.2015140309

Nicholson, P.T., S. Ikram \& S. Mills. 2015. The catacombs of Anubis at North Saqqara. Antiquity 89: 645-61.

https://doi.org/10.15184/aqy.2014.53
Pinch, G. \& E.A. Waraksa. 2009. Votive practices, in J. Dieleman \& W. Wendrich (ed.) UCLA encyclopedia of Egyptology. Los Angeles: University of California Los Angeles.

Raven, M. \& W.K.E. Taconis. 2005. Egyptian mummies: radiological atlas of the collections in the National Museum of Antiquities in Leiden. Brepols: Turnhout.

RAY, J. 2001. Reflections of Osiris: lives from ancient Egypt. Oxford: Oxford University Press.

- 2013. Demotic Ostraca and other inscriptions from the Sacred Animal Necropolis, North Saqqara. London: Egypt Exploration Society.

Stevenson, A. 2015. Between the field and the museum: the ongoing project of archaeological context. Egyptian and Egyptological Documents Archives Libraries 4: 109-18.

Stevenson, A., E. Libonati \& A. Williams. 2016. 'A selection of minor antiquities': a multi-sited view on collections from excavations in Egypt. World Archaeology 48: Collection.

Szpakowska, K. \& R. Johnston. 2016. Snake busters: experiments in fracture patterns of ritual figurines, in C. Price, R. Forshaw,

A. Chamberlain \& P. Nicholson (ed.) Mummies, magic and medicine in ancient Egypt: multidisciplinary essays for Rosalie David: 461-75. Manchester: Manchester University Press. https://doi.org/10.7765/9781784997502.00050

Thompson, D.J. 2012. Memphis under the Ptolemies. Princeton (NJ): Princeton University Press.

Wildung, D. 1977. Egyptian saints: deification in pharaonic Egypt. New York: New York University Press.

Received: 12 April 2017; Revised: 24 July 2018; Accepted: 24 August 2018

(C) Antiquity Publications Ltd, 2019 